\title{
Bacteriological Quality Analysis of Milk Available in Local Market of Janakpurdham, Nepal
}

\author{
Nagendra Prasad Yadav ${ }^{1 *}$, Rakesh Kumar Yadav², Bishal Pokharel ${ }^{3}$ \\ ${ }^{1}$ Department of Microbiology, Model Multiple College, Janakpur \\ ${ }^{2}$ Department of Pharmacology, Janaki Medical College, Janakpur \\ ${ }^{3}$ Department of Community Medicine, Janaki Medical College, Janakpur
}

\begin{abstract}
*Corresponding author: Nagendra Prasad Yadav, Department of Microbiology, Model Multiple College, Janakpur, Nepal; E-mail: nagendrayadav2073@gmail.com
\end{abstract}

\begin{abstract}
Objectives: To determine the microbial quality of milk available in the market of Janakpurdham, Nepal.

Methods: Total 20 samples of milk were collected from the market and processed for MBRT test as per standard protocol. Reduction time test for each sample of the milk was recorded in a specified format and analysed statistically.

Results: Out of 20 samples, 2 (10\%) samples were found of excellent quality, 3 (15\%) were of good quality, $6(30 \%)$ were of fair quality and $9(45 \%)$ were of poor quality. Unprocessed milk was found to be highly contaminated in comparison to the processed milk.

Conclusion: Unprocessed milk was found to be highly contaminated and not fit for the human consumption.
\end{abstract}

Key words: Milk, MBRT, microbial quality

\section{INTRODUCTION}

Milk may be defined in various ways. Chemically speaking, milk is a complex fluid in which more than 100 separate chemical compounds have been found. Its major components are water, fat, lactose, casein, whey proteins, and minerals (or ash) in amounts varying with the milk of various species of animals (JP et al. 1994). However, for any given species, the range of values for the constituents of milk is fairly constant. From a physiological standpoint, milk is the secretion of the normally functioning mammary gland of the females of all mammals, which is produced for some time following parturition for the nourishment of the young of the species during the initial period of growth. In terms of physical chemistry, milk is an opaque, whitish fluid of multi disperse phases. The true solution contains lactose, vitamins, acids, enzymes, and some inorganic salts. The colloidal phase contains casein, calcium phosphate, and globular proteins. Fat exists in

Date of Submission: August 8, 2018

Published Online: January 2019 the form of an oil-in-water type of emulsion, with fat globules varying from 0.1 to $22 \mu \mathrm{m}$ in diameter (Wong et al. 1988).

As a food ingredient or consumed by itself, milk provides an excellent nutritional profile in the human diet. Nutrition experts consider milk an exceptionally complete food because it contains significant levels of required nutrients such as protein, fat, carbohydrates, minerals, and several vitamins. Low-fat and no fat milks are increasingly popular in fat-reduced and fatfree food formulations (FAO 1993). Worldwide, milk of the cow is by far of more commercial importance than milk of any other mammal. In the United States, the term "milk" legally refers to cow's milk. Milk from other species is labelled to indicate the type: sheep's milk, goat's milk, etc. Milk is the whole, clean lacteal secretion of one or more healthy cows properly fed and kept, excluding that obtained within 15 days before calving and three to five days after. Colostrum,

Date of Acceptance: December 10, 2018

DOI: https:/ / doi.org/10.3126/tujm.v5i0.22321 
the milk secreted immediately after giving birth, is not considered milk from a legal standpoint. The U.S. Public Health Service's definition of Grade A milk is "the lacteal secretion practically free from colostrum, obtained by complete milking of one or more healthy cows, which contains not less than $8.25 \%$ milk solidsnot-fat (MSNF) and not less than 3.25\% milk fat (Singh et al. 1997; Harper et al. 1996).

Milkis agood medium for the growth of microorganisms. These active growing microorganisms reduce the oxidation reduction potential of the milk medium due to the exhausted oxygen by the microorganism. Normally the milk is contaminated with organisms such as Staphylococcusaureus, Streptococcuspyogenes, Pseudomonas etc. Contaminated milk is one of the important sources for transmission of diseases from animals to humans. The main reason for this contamination is the improper handling of milk. Normally milk is contaminated during the milking process by the microorganisms present in the exterior surface of the animals, pipelines such as udder and adjacent areas. Unsterilized dairy utensils such as milking machines, milk cans are also a good source of contamination by the microorganisms (Walstra and Jenness 1993). The formation of methylene blue reductase is thus becoming a popular tool for determining the quality of the milk. The principle of methylene blue reduction test depends on the fact that the colour imparted to the milk by adding a dye such as methylene blue will disappear more or less quickly which depends on the quality of the milk sample to be examined. Methylene blue is a redox indicator that loses its colour under the absence of oxygen and is thought to be reduced. The depletion of oxygen in the milk is due to the production of reducing substance in the milk due to the enhanced rate of bacterial metabolism. The dye reduction time refers to the microbial load in the milk and the total metabolic reaction of the microorganism (Aurand and Woods 1984).

\section{MATERIALS AND METHODS}

The samples of milk were collected from different areas of Janakpur market. Sample collections were lasted from May to June, 2017. Sampling was performed according to standard protocol for the examination of milk. All milk samples were collected from 3 different sources comprising of 5 cows milk, 6 buffalo milk and 9 DDC milk. Total 20 samples of milk were collected aseptically and processed for MBRT test as per standard protocol. Reduction time test for each sample of the milk was recorded in a specified format and analysed statistically.

\section{RESULTS}

A total of 20 samples were examined physically and then proceed for the MBRT test. Out of 20 samples, 2 (10\%) samples were found excellent quality, 3 (15\%) were of good quality, 6 (30\%) were of fair quality and $9(45 \%)$ were of poor quality. Among these 20 samples, 6 samples were of processed milk, 5 samples were of unprocessed/ raw milk and 9 samples were of Diary Development Corporation milk.

Table 1: MBRT table of processed milk

\begin{tabular}{lcc}
\hline Samples & Reduction time (hrs) & Quality \\
\hline Cow milk & 3.5 & Good \\
Cow milk & 6.0 & Excellent \\
Buffalo milk & 4.0 & Good \\
Cow milk & 2.5 & Fair \\
Buffalo milk & 0.5 & Poor \\
Buffalo milk & 1.5 & Fair \\
\hline
\end{tabular}

Table 2: MBRT table of unprocessed milk

\begin{tabular}{lcc}
\hline Sample & Reduction time (Hrs) & Quality \\
\hline Cow milk & 2.0 & Fair \\
Buffalo milk & 0.75 & Poor \\
Buffalo milk & 1.5 & Fair \\
Buffalo milk & 0.5 & Poor \\
Cow milk & $1 / 2 \mathrm{hrs}$ & Poor \\
\hline
\end{tabular}


Table 3: MBRT of DDC milk

\begin{tabular}{lcc}
\hline Sample & Reduction Time (hrs) & Quality \\
\hline DDC milk & 3.5 & Good \\
DDC milk & 8.0 & Excellent \\
DDC milk & 1.5 & Fair \\
DDC milk & 2.0 & Fair \\
DDC milk & 2.5 & Fair \\
DDC milk & 1.5 & Fair \\
DDC milk & 2.5 & Fair \\
DDC milk & 2 & Fair \\
DDC milk & 2 & Fair \\
\hline
\end{tabular}

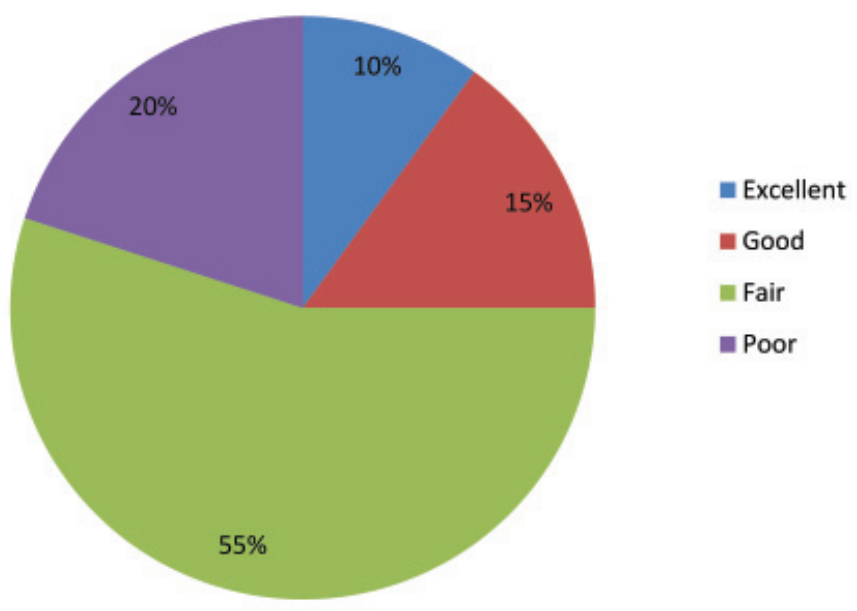

Figure 1: Percentage of quality of milk available in different areas of Janakpur market

\section{DISCUSSION}

Milk is the important source of protein. It help us to develop the brain sharpens our memory, make us powerful. Though nowadays people, for their selfish motive of earning money they mix harmful chemicals in the milk just to increase its qualitquantity. Thus milk quality is lowered and human immune system is also lowered and are suffering from many diseases (NDC 1993). The methylene blue reduction test is based on the fact that the color imparted to milk by the addition of a dye such as methylene blue will disappear more or less quickly. The removal of the oxygen from milk and the formation of reducing substances during bacterial metabolism cause the color to disappear. Oxygen is consumed by the bacteria the greater the number of bacteria in milk, the quicker will the oxygen be consumed, \& in turn the sooner will the color disappear. Thus the time of reduction is taken as a measure of the number of organism in milk (Aurand and Woods 1984).
In this study, 20 milk samples from different local areas of janakpur tested. Out of 20 samples 2(10\%) were of excellent, $3(15 \%)$ were good, $6(30 \%)$ were fair and 9 (45\%) were of poor quality. Among these 20 samples, 6 samples were of processed milk, 5 samples were of unprocessed/raw milk and 9 samples were of DDC milk.

\section{CONCLUSION}

The quality of milk was found very poor in raw milk. The quality of DDC milk i.e. pasteurized was good and it is suitable for human consumption. Milk samples which were not processed found contaminated. Thus to prevent from the milk borne diseases pasteurized milk should be consumed.

\section{ACKNOWLEDGEMENTS}

The authors are thankful to Model Multiple College for providing laboratory facilities. Thanks are due to the farmers for providing milk sample for this study. 


\section{REFERENCES}

Abele CA and Ahuja CH (1945). The methylene blue reduction test as a measure of estimating the bacterial content of milk to determine its suitability for pasteurization or as a basic of grading. J Milk and Food Tech.

Aurand LW and Woods AE (1959). Role of xanthine oxidase in the development of spontaneously oxidized flavor in milk. J Dairy Sci 4: 111.

BS. 1741. part 11, pearson's composition and analysis of foods $9^{\text {th }}$ edn 1991, page 549.

FAO (2003). Manual of food quality control, 14/8, page 8/15.1479 (part1)1961 (Reaffirmed 2003) methods of test for dairy industry-Rapid examination of milk. Bureau of Indian standard, New Delhi.

Harper WJ and Hall CW (1976). Dairy technology and engineering. AVI publishing $\mathrm{CO}$ west port $\mathrm{CT}$.

IS (1166-1986) (1991). Specification for condensed milk -modified lane and eynon volumetric method. Bureau of Indian standard, New Delhi, Pearson's composition and analysis of foods, $9^{\text {th }}$ Edn.

IS 1479-1961 (2003). Methods of test for dairy industryRapid Examination of milk. Bureau of Indian standard, New Delhi.
IS 1479-1961 (1997). Methods of test for dairy industrychemical analysis of milk. Bureau of Indian standard, New Delhi.

ICMR (1990). Method of analysis for adulterants and contamints in foods, page 28 .

Roy NK and Sen DC (1991). Rapid analysis of milk. In Textbook of practical dairy chemistry vol1. Chemical analysis of fluid milk, Kalyani publisher, New Delhi, India.

National Dairy Council (1993). Knowledge of milk and other fluid dairy products. The Council, Rosemont I.

Singh H, Mccarthy OJ, and Luccey JA (1997). Physicochemical properties of milk. In advantage, vol3. PF Fox, Ed. Chapman and Hall .

Varnum AH and Sutherland JP (1994). Milk and milk products champman and Hall New York.

Walstra P and Jenness R (1984). Dairy chemistry and physics. John Wiley New York.

Wong NP, Jenness R, Keeney M and Marth EH (1988). Fundamentals of dairy chemistry, $3^{\text {rd }} \mathrm{ed}$. Van Nostrand Reinhold, New York. 